\title{
MATHEMATICAL MODELING OF DISTILLERY WASTEWATERS BIOMETHANATION IN FLUIDIZED-BED BIOREACTOR
}

\author{
Sk Masud Hossain ${ }^{* 1}$, Manas Das ${ }^{2}$ \\ ${ }^{1}$ Centre for Advanced Studies and Research, Younus College of Engineering E Technology, Kollam 691010, Kerala, India \\ ${ }^{2}$ Department of Chemical Engineering, University of Calcutta, 92 A P C Road, Kolkata 700009, West Bengal, India
}

Received 25 January 2010; received in revised form 3 April 2010

\begin{abstract}
An anaerobic fluidized- bed reactor was designed to treat distillery wastewaters for biogas generation using actively digested aerobic sludge of a sewage plant. The optimum digestion time was $8 \mathrm{~h}$ and optimum initial $\mathrm{pH}$ of feed was observed as 7.5 respectively. The optimum temperature of feed was $40^{\circ} \mathrm{C}$ and optimum feed flow is $14 \mathrm{~L} /$ min with maximum OLR was $39.513 \mathrm{~kg} \mathrm{COD} \mathrm{m}^{-3} \mathrm{~h}^{-1}$ respectively. The OLR was calculated on the basis of COD inlet in the bioreactor at different flow rates. Maximum $\mathrm{CH}_{4}$ gas concentration was $63.56 \%(\mathrm{v} / \mathrm{v})$ of the total $\left(0.835 \mathrm{~m}^{3} / \mathrm{kg} \mathrm{COD} \mathrm{m}^{-3} \mathrm{~h}^{-1}\right)$ biogas generation, corresponding to $0.530 \mathrm{~m}^{3} / \mathrm{kg} \mathrm{COD} \mathrm{m}^{-3} \mathrm{~h}^{-1}$ at optimum digestion parameters. Maximum COD and BOD reduction of the distillery wastewaters were $76.82 \%(\mathrm{w} / \mathrm{w})$ and $81.65 \%(\mathrm{w} / \mathrm{w})$ with maximum OLR of $39.513 \mathrm{~kg} \mathrm{COD} \mathrm{m}^{-3} \mathrm{~h}^{-1}$ at optimum conditions respectively. The rate constant $(k)$ was measured as $0.31 \mathrm{~h}^{-1}$ in fluidized-bed bioreactor and followed a first order rate equation. The specific growth rate $(\mu)$ was $0.99 \mathrm{~h}^{-1}$ and maximum sp. growth rate $\left(\mu_{\max }\right)$ was $1.98 \mathrm{~h}^{-1}$ respectively. The bacterial yield coefficient $(Y)$ was determined as $0.319 / \mathrm{kg} \mathrm{COD} \mathrm{m}^{-3} \mathrm{~h}^{-1}$ at optimum parameters. The studies also dealt with the mathematical modeling of the experimental data on biomethanation and suggested modeling equations relating to kinetic parameter (rate constant, $k$ ), maximum specific growth rate $\left(\mu_{\max }\right)$ with respect to COD (substrate) removal. The mathematical model was also analyzed for hydrodynamic pressure $(\Delta p)$ vs feed flow $(u)$ and hydrodynamic pressure $(\Delta p)$ with respect to $\mathrm{CH}_{4}$ gas yields. The linear and non-linear equations which fitted the models were obtained.
\end{abstract}

Keywords: Biomethanation, anaerobic, optimum condition, modeling

DOI:10.3329/cerb.v14i1.4224

\section{Introduction}

The energy crisis of the early 1970s brought into sharp focus the vital importance of the extent biomass energy base in the face of destabilized global trade in fossil energy. Since the bulk of energy used in developing countries is in the form of biomass energy formal household consumption, the energy crisis has, in reality, became biomass energy crisis in those countries. Much of the present-day technology is fueled by biomass of carboniferous era. To a varying extent, this fossil biomass energy resource is supplemented all over the world by energy obtainable from extant biomass. A reassessment of conventional biomass energy production and conversion technologies is pertinent at this stage. The bulk of biomass energy is currently derived from vegetarian and from agricultural crop residues [1-5]. Biogas production is of major importance for the sustainable use of agrarian biomass as renewable energy source. In a few instances, municipal wastes and such sources as peat form additional sources of biomass energy. A more possible alternative is to use of industrial cellulosic wastewaters, wastewaters and effluents to satisfy the ecological balances and pollution abatement [6-29].

Since the early 70s, anaerobic digestion of industrial waste-waters has gained considerably in importance. It is concluded that while the anaerobic fluidized- bed process

*Corresponding author, Email:skmhossain@yahoo.co.in has become an established technology for biomethanation of treatment of industrial waste-waters, further improvements can still be expected. Attached bacteria have the highest relative activities and are considered to have a more important role in anaerobic stabilization than the unattached portion [16-19]. Biomass concentration in the bottom part of the bed showed higher values than in the upper levels in the fluidized bed reactor. On the other hand, biofilm density increased towards the reactor bottom, wherein it showed the highest values. The assays indicated that total activity was higher in bioparticle sampled from upper reactor levels. This was explained by the lower biofilm density values in this zone and mass transfer limitation phenomena [16-19].

Perez et al [8] examined the effect of organic loading rate (OLR) on the removal efficiency of Chemical Oxygen Demands (COD) and total organic carbon (TOC) anaerobic thermophilic fluidized bed reactor (AFBR) in the treatment of cutting-oil wastewater at different hydraulic retention time (HRT) conditions. Acharya et al [9] studied on anaerobic digestion of wastewater from a distillery industry having very high COD and Biological Oxygen demands (BOD) was fed in a continuous upflow fixed film column reactor using different support materials such as charcoal, coconut coir and nylon fibers under varying HRT and OLR respectively.

The present investigations were undertaken for an effective anaerobic biomethanation of distillery wastewaters using aerobic activated digested sludge from sewage plant for biogas generation in fluidized- bed bioreactor. Attempts 
were made to optimize digestion time, initial feed $\mathrm{pH}$, feed temperature and feed flow (OLR) to obtain maximum $\mathrm{CH}_{4}$ gas generation and removal of COD and BOD of distillery wastewaters. The kinetics of anaerobic biomethanation of the distillery wastewaters with respect to COD removal in fluidized-bed bioreactor was also investigated. The studies dealt with the mathematical modeling of the experimental data on biomethanation and suggest model equations relating kinetic parameter (rate constant, $k$ ), maximum specific growth rate $\left(\mu_{\max }\right)$ with respect to COD (substrate) removal [15-19]. The mathematical model was also analyzed for hydrodynamic pressure $(\Delta p)$ vs feed flow $(u)$ and hydrodynamic pressure $(\Delta p)$ with respect to $\mathrm{CH}_{4}$ gas yields.

\section{Experimental}

\subsection{Collection of seed and suspension culture preparation}

Actively digesting sludge was collected from the local aerobic sewage plant constitutes ideal "seed" material. It was transferred to suspension culture media and incubated at $30^{\circ} \mathrm{C}$ for 7 days in an incubator for sufficient bacterial population. The resulting methagenic bacterial cell suspensions were filtered through several layers of sterile absorbent cotton. The bacterial population was counted as $7.1 \times 10^{8}$ numbers of cells per $\mathrm{mL}$ of the suspension culture [30]. This bacterial suspension culture was used for the present studies. The following constituents were used for suspension culture media preparation per liter: $\mathrm{KH}_{2} \mathrm{PO}_{4}-20 \mathrm{~g}, \mathrm{MgSO}_{4} \cdot 7 \mathrm{H}_{2} \mathrm{O}-5.0 \mathrm{~g}, \mathrm{CaCl}_{2}-1.0 \mathrm{~g}$, $\mathrm{MnSO}_{4} \cdot 7 \mathrm{H}_{2} \mathrm{O}-0.05 \mathrm{~g}, \mathrm{FeSO}_{4} \cdot 7 \mathrm{H}_{2} \mathrm{O}-0.10 \mathrm{~g}, \mathrm{CaCl}_{2} \cdot 6 \mathrm{H}_{2} \mathrm{O}-$ $0.10 \mathrm{~g}, \mathrm{AlK}\left(\mathrm{SO}_{4}\right)_{2} \cdot 12 \mathrm{H}_{2} \mathrm{O}-0.01 \mathrm{~g}, \mathrm{Na}_{2} \mathrm{MoO}_{4} \cdot 2 \mathrm{H}_{2} \mathrm{O}-0.01 \mathrm{~g}$.

\subsection{Collection and analysis of distillery wastewater}

The distillery wastewater was collected from indigenous source and stored in freeze at $4^{\circ} \mathrm{C}$. The sample was analyzed for $\operatorname{COD}(95,785 \mathrm{mg} / \mathrm{L})$ and $\mathrm{BOD}(72,655 \mathrm{mg} / \mathrm{L})$ respectively.

\subsection{Experimental setup}

The experimental setup of fluidized-bed bioreactor (M/S Appex Innovations Ltd) is shown in Figure 1. The distillery wastewaters entered at the bottom and passed through the fluidized-bed bioreactor (volume: $0.0186 \mathrm{~m}^{3}$; column dia: $13 \times 10^{-2} \mathrm{~m}$ ) and left from upward. The flow had a velocity sufficient to expand the bed without necessarily causing vigorous agitation, which resulted in complete mixing of the wastewaters and methagenic bacteria. The spherical glass particle ( dia, $5 \times 10^{-4} \mathrm{~m}$; solid particle density, $2230 \mathrm{~kg} / \mathrm{m}^{3}$ ) that allowed low energy requirements for fluidization, also, provided a good surface for biomass attachment (biofilm formation) and development. It was assumed that most particles had been covered with a thin biofilm of uniform thickness. Outlet digested feed was recycled to the feed tank (Figure 1). The biogas was collected in a gas holder (The gas holder is normally an airproof steel container that, by floating like a ball on the fermentation mix, cuts off air to the digester and collects the gas generate) fitted with a Flame-Ionization Detector (FID) for $\mathrm{CH}_{4}$ gas analysis [30].

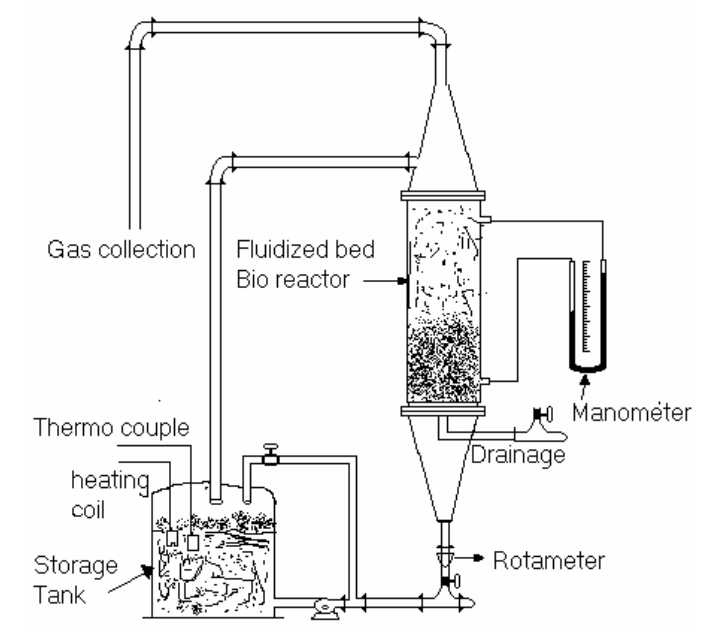

Figure 1: Experimental setup of fluidized bed bioreactor

\subsection{General method}

Experiments were carried out in $50 \mathrm{~L}$ plastic tank containing $20 \mathrm{~L}$ of raw wastewaters as feed to be digested for biogas generation. Equal volumes $(20 \mathrm{~L})$ of suspension mixed methagenic bacterial culture as inoculum were added to the feed tank. $20 \mathrm{~L}$ of suspension culture media were added to the feed tank contents. The initial $\mathrm{pH}$ of feed in tank was maintained at 6.0 by using $0.1 \mathrm{~N} \mathrm{H}_{2} \mathrm{SO}_{4}$ acid and/or $1 \mathrm{M}$ $\mathrm{CaCO}_{3}$ slurry. The temperature of the feed was maintained at $30^{\circ} \mathrm{C}$ by means of heating coil fitted with off-on temperature controller. The temperature of feed was measured by a thermocouple. The feed was pumped to fluidized-bed bioreactor form the feed tank. The initial feed flow was maintained at $10 \mathrm{~L} / \mathrm{min}\left(\mathrm{OLR} 28.224 \mathrm{~kg} \mathrm{COD} \mathrm{m}^{-3} \mathrm{~h}^{-1}\right)$ through a rotameter (Figure 1). After each operation, the digested feed was discharged through a valve.

\subsection{Effect of Digestion Time, Initial Feed pH, Feed Temper- ature and Feed Flow}

The concentrations of $\mathrm{CH}_{4}$ gas in the biogas were measured on a regular interval $(2,4,6,8,10$ and $12 \mathrm{~h})$ of time and analyzed for COD and BOD in digested feed. The concentrations of $\mathrm{CH}_{4}$ gas were measured at optimum digestion time $(8 \mathrm{~h})$ for various $\mathrm{pH}$ values $(6.5,7.0,7.5$ and 8.0$)$ and analyzed for COD and BOD in digested feed. $\mathrm{CH}_{4}$ gas concentrations were measured at optimum digestion time $(8 \mathrm{~h})$ and $\mathrm{pH}(7.5)$ for various temperatures $\left(35,40\right.$ and $\left.45^{\circ} \mathrm{C}\right)$ and analyzed for $\mathrm{COD}$ and BOD in digested feed. $\mathrm{CH}_{4}$ gas concentrations were measured at optimum time $(8 \mathrm{~h}), \mathrm{pH}(7.5)$ and temperature $\left(40^{\circ} \mathrm{C}\right)$ for various feed flow $(12 \mathrm{~L} / \mathrm{min}, 14$ $\mathrm{L} / \min , 16 \mathrm{~L} / \min$ and $18 \mathrm{~L} / \mathrm{min}$ ) and analyzed for COD and $\mathrm{BOD}$ in digested feed.

\subsection{Analysis of methane}

The analysis of biogas containing methane was carried out in the Flame-Ionization Detector (FID) [31]. The eluate coming from the column was mixed with hydrogen (the fuel) and then burned in a stream of air (the oxidant) to form 
a combustible mixture in FID (M/S Ametek Process Instruments, Inc). The ignited mixture yielded a flame which provides the energy to ionize sample component in the eluate. The temperature $\left(1800^{\circ} \mathrm{C}\right)$ of the air-hydrogen flame was used to ionize only carbon compounds. The positive ions thus formed during ionization in the flame were attracted to a negative"Collector" electrode and repelled by a positive "Repeller" electrode. The repeller electrode was either the metal burner or an electrode placed near the base of the flame. Upon striking the collector electrode, the positive ions cause a current to flow in the external circuit connecting the positive and negative electrodes. The current was amplified and recorded. The current flowing through the circuit was proportional to the number of ions striking the collector, which in turn was proportional to the concentration of sample $\mathrm{CH}_{4}$ gas entering the flame. It was calibrated by standard $\mathrm{CH}_{4}$ gas.

\section{Results and Discussion}

\subsection{Effect of digestion time}

The concentration and yield of $\mathrm{CH}_{4}$ gas were proportional to time. The concentration and yield of methane $(\mathrm{CH} 4)$ gas increase with increase of time up to $8 \mathrm{~h}$ and then both decline (Figure 2). It was observed that maximum biogas yield from distillery wastewaters is $0.682 \mathrm{~m}^{3} / \mathrm{kg} \mathrm{COD} \mathrm{m}{ }^{-3} \mathrm{~h}^{-1}$ at $8 \mathrm{~h}$ of digestion time (Figure 2). Maximum $\mathrm{CH} 4$ gas yields was 47.85 percent $(\mathrm{v} / \mathrm{v})$ corresponding to $0.326 \mathrm{~m}^{3} / \mathrm{kg} \mathrm{COD} \mathrm{m}^{-3}$ $\mathrm{h}^{-1}$ at time of $8 \mathrm{~h}$ (Figure 2$)$ at temperature $\left(30^{\circ} \mathrm{C}\right)$ and prevalent pressure $\left(1393.265 \mathrm{kN} / \mathrm{m}^{2}\right)$ in three-phase fluidized-bed bioreactor.

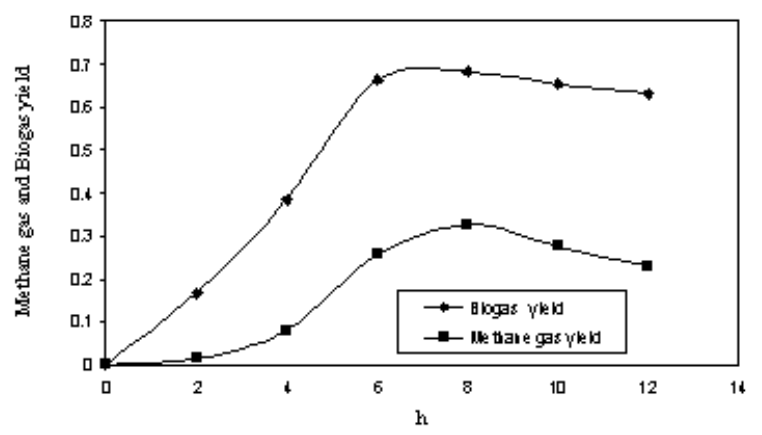

Figure 2: Effect of hydraulic retention time on biogas and methane yield

The removals of COD and BOD in the biomethanation of distillery wastewaters were 54.96 percent $(\mathrm{w} / \mathrm{w})$ and 57.65 percent $(w / w)$ respectively at time of $8 \mathrm{~h}$ (Figure 3). After $8 \mathrm{~h}$ digestion time, the removal of COD and BOD from wastewaters was decreased and yields of biogas and $\mathrm{CH}_{4}$ gas was also declined. Therefore, digestion time of $8 \mathrm{~h}$ was optimum for biomethanation process in the fluidized- bed bioreactor. At the early stage of biomethanation, which coincided with lag-phase of bacterial growth, the removal of COD and BOD and yield of $\mathrm{CH} 4$ gas were very low. The transition of bacterial growth from the lag-phase to exponential phase led to a notable increase in $\mathrm{CH} 4$ gas yield, which proceeded with same until it reached maximum $\left(0.326 \mathrm{~m}^{3} / \mathrm{kg} \mathrm{COD} \mathrm{m}^{-3} \mathrm{~h}^{-1}\right)$ at optimum time of $8 \mathrm{~h}$. It was evident from the Figure 2 that as the digestion time increased $(>8 \mathrm{~h})$, the yield of $\mathrm{CH}_{4}$ gas by the mixed methagenic bacteria decreased due to death phase of bacteria.

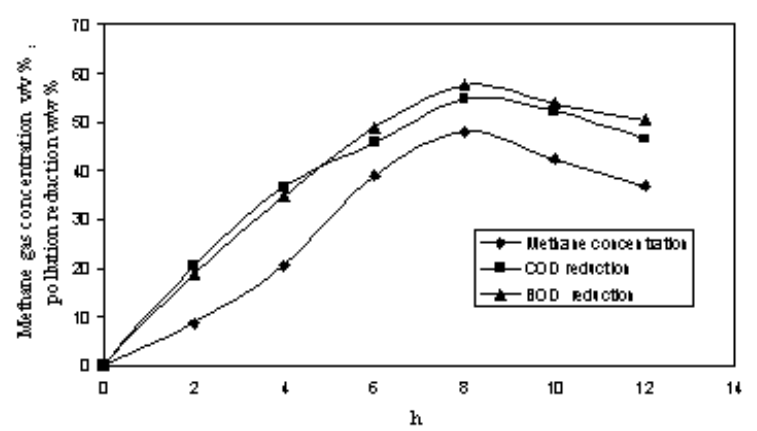

Figure 3: Effect of hydraulic retention time on COD and BOD reduction

\subsection{Effect of initial feed $p H$}

Initial feed $\mathrm{pH}$ was taken both in acidic and basic medium range. The increase in yields and concentrations of $\mathrm{CH}_{4}$ gas were observed with increase in initial $\mathrm{pH}$ of the feed upto 7.5 and then both were declined. It was observed that maximum biogas yield from distillery wastewaters was $0.718 \mathrm{~m}^{3} / \mathrm{kg}$ $\mathrm{COD} \mathrm{m}{ }^{-3} \mathrm{~h}^{-1}$ at feed $\mathrm{pH}$ of 7.5 at optimum digestion time (Figure 4). $\mathrm{CH}_{4}$ gas concentration was 52.36 percent (v/v) at feed $\mathrm{pH}$ of 7.5 with mixed mutagenic bacteria (Figure 5). Maximum $\mathrm{CH}_{4}$ gas yields was $0.375 \mathrm{~m}^{3} / \mathrm{kg} \mathrm{COD} \mathrm{m}^{-3} \mathrm{~h}^{-1}$ at feed $\mathrm{pH}$ of 7.5 at temperature $\left(30^{\circ} \mathrm{C}\right)$ and prevalent pressure $\left(1393.265 \mathrm{kN} / \mathrm{m}^{2}\right)$ in three-phase fluidized-bed bioreactor. With increase in feed $\mathrm{pH}(>7.5)$, the concentrations as well as the yield of $\mathrm{CH}_{4}$ gas were sharply decreased .

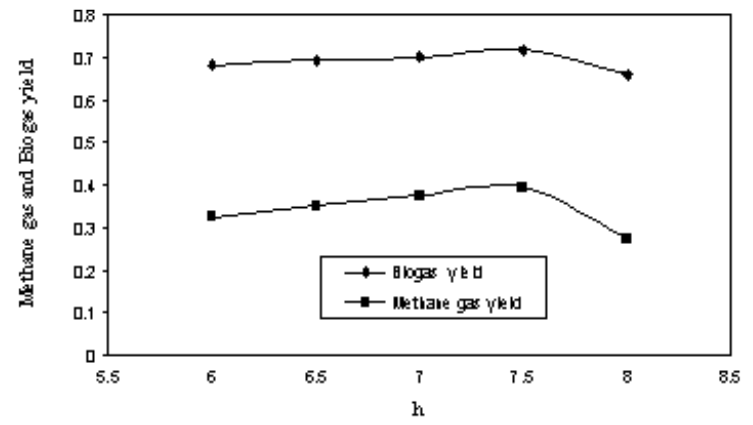

Figure 4: Effect of initial $\mathrm{pH}$ on biogas and methane yield

It was also observed that a maximum COD removal in the biomethanation process of distillery wastewaters was 63.80 percent (w/w) at feed $\mathrm{pH}$ of 7.5 (Fig. 5). A maximum BOD removal from distillery wastewaters was 66.72 percent $(w / w)$ at feed $\mathrm{pH}$ of 7.5. Then, the removals of COD and BOD decreased beyond optimum (7.5) $\mathrm{pH}$. Therefore, initial feed $\mathrm{pH}$ of 7.5 was the optimum for maximum yield of $\mathrm{CH}_{4}$ and removal of COD and BOD from distillery wastewaters in a fluidized-bed bioreactor in biomethanation process. Variations in $\mathrm{pH}$ of the feed resulted in changes in the activity of 


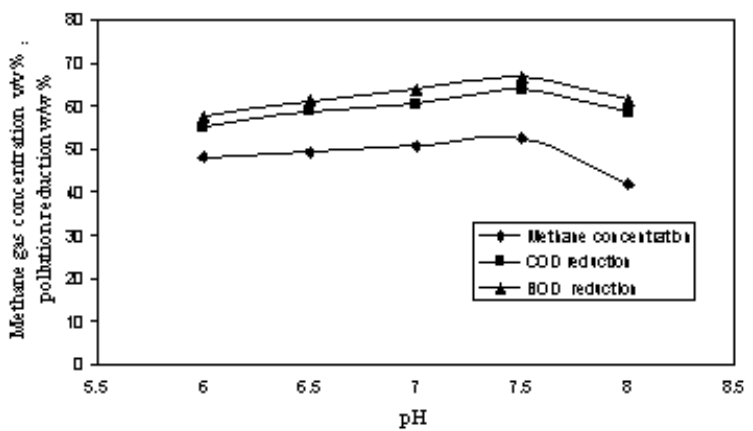

Figure 5: Effect of initial $\mathrm{pH}$ on $\mathrm{COD}$ and BOD reduction

the mixed methgenic bacteria and hence the bacterial growth as well as the $\mathrm{CH}_{4}$ generation. Methagenic bacteria were very active over a certain $\mathrm{pH}$ range. When $\mathrm{pH}$ differed from the optimal value $(>7.5)$, the maintenance energy requirements increase that lead to decrease in bacterial population and biogas yields [32].

\subsection{Effect of feed temperature}

The effect of feed temperature on anaerobic biogas and $\mathrm{CH}_{4}$ gas generation from distillery wastewater in fluidizedbed bioreactor is shown in Figure 6 and 7 respectively. The feed temperature was in the mesophilic range. With increase in temperature, the yields and concentrations $\mathrm{CH}_{4}$ gas increased up to feed temperature of $40^{\circ} \mathrm{C}$ and then both decreased. The biogas yield from distillery wastewaters was $0.741 \mathrm{~m}^{3} / \mathrm{kg} \mathrm{COD} \mathrm{m}^{-3} \mathrm{~h}^{-1}$ at feed temperature of $40^{\circ} \mathrm{C}$ at optimum conditions. The concentration of methane gas was 57.26 percent $(\mathrm{v} / \mathrm{v})$ at feed temperatures of $40^{\circ} \mathrm{C} . \mathrm{CH}_{4}$ gas yield in fluidized-bed bioreactor was $0.424 \mathrm{~m}^{3} / \mathrm{kg} \mathrm{COD} \mathrm{m}^{-3}$ $\mathrm{h}^{-1}$ at optimum temperature $\left(40^{\circ} \mathrm{C}\right)$ and prevalent pressure $\left(1393.265 \mathrm{kN} / \mathrm{m}^{2}\right)$ in three-phase fluidized-bed bioreactor.

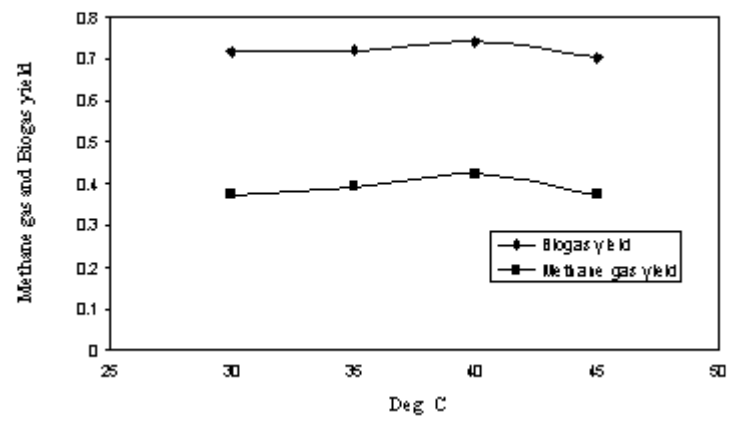

Figure 6: Effect of feed temperature on biogas and methane yield

Maximum COD removal in the biomethanation of the distillery wastewaters was 69.83 percent $(\mathrm{w} / \mathrm{w})$ at feed temperature $40^{\circ} \mathrm{C}$. Maximum BOD removal in the biomethanation of distillery wastewaters was 74.45 percent (w/w) at temperature $40^{\circ} \mathrm{C}$. With increase in feed temperature $\left(>40^{\circ} \mathrm{C}\right), \mathrm{CH}_{4}$ gas yields and the removal of COD and BOD from distillery wastewaters declined as well. Therefore, feed temperature of $40^{\circ} \mathrm{C}$ was the optimum for maximum yield of methane

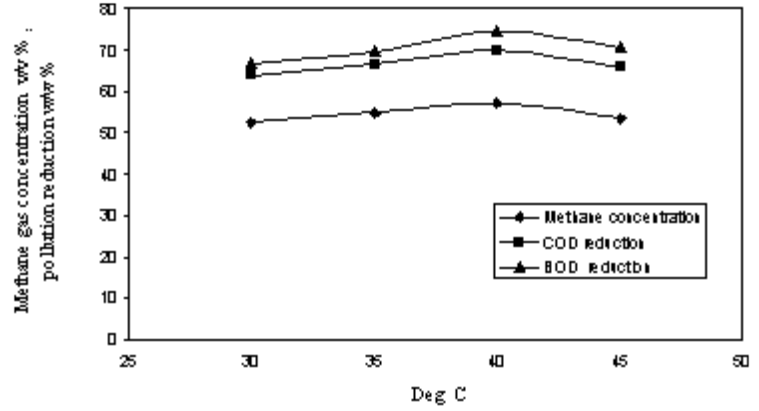

Figure 7: Effect of feed temperature on COD and BOD reduction

gas and removal of COD and BOD from distillery wastewaters in a fluidized- bed bioreactor in biomethanation process. Temperatures below the optimum $\left(<40^{\circ} \mathrm{C}\right)$ depressed the rate of metabolism of bacterial cells. At higher temperature $\left(>40^{\circ} \mathrm{C}\right)$, the growth rate decreased and thermal death occurred [32]. At higher temperature $\left(>40^{\circ} \mathrm{C}\right)$, death rate exceeded the growth rate, which causes a net decrease in the concentration of viable bacterial populations [32] with lower generation of $\mathrm{CH}_{4}$ gas as well as COD and BOD removal.

\subsection{Effect of feed flow}

The OLR was calculated on the basis COD inlet in the reactor only with different feed flow. With increase in feed flow, the yield and concentration of $\mathrm{CH} 4$ gas increased up to $14 \mathrm{~L} / \mathrm{min}$ and then both decreased. It was noticed that biogas yields in anaerobic fluidized-bed bioreactor was $0.835 \mathrm{~m}^{3}$ $/ \mathrm{kg} \mathrm{COD} \mathrm{m}^{-3} \mathrm{~h}^{-1}$ at feed flow rate of $14 \mathrm{~L} / \mathrm{min}$ at optimum biomethanation conditions (Figure 8). The concentration of $\mathrm{CH}_{4}$ gas was 63.56 percent (v/v) at feed flow of $14 \mathrm{~L} / \mathrm{min}$ (Figure 9). $\mathrm{CH}_{4}$ gas yields in anaerobic fluidized-bed bioreactor was $0.530 \mathrm{~m}^{3} / \mathrm{kg} \mathrm{COD} \mathrm{m}^{-3} \mathrm{~h}^{-1}$ at feed flow of $14 \mathrm{~L} /$ min at optimum temperature $\left(40^{\circ} \mathrm{C}\right)$ and prevalent pressure $\left(1708.264 \mathrm{kN} / \mathrm{m}^{2}\right)$ in three-phase fluidized-bed bioreactor. With increase in feed flow ( $>14 \mathrm{~L} / \mathrm{min})$, the yield and concentration of methane gas were declined.

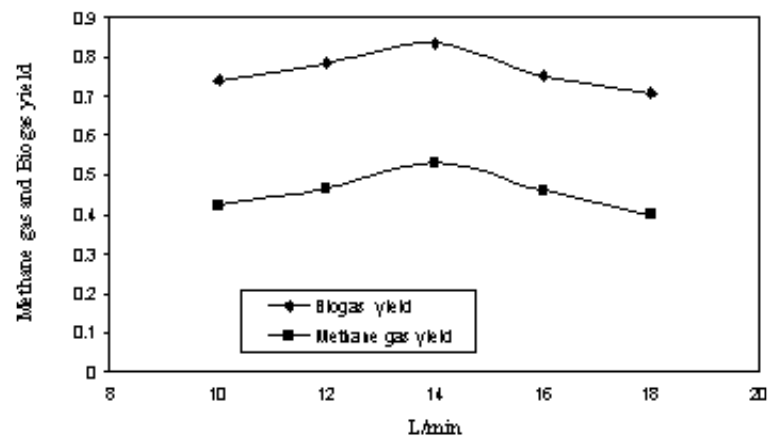

Figure 8: Effect of feed flowrate on biogas and methane yield

Maximum COD removal in the biomethanation of the distillery wastewaters was 76.82 percent $(w / w)$ at feed flow of $14 \mathrm{~L} / \mathrm{min}$. Maximum BOD removal in biomethanation of the distillery wastewaters was 81.65 percent $(\mathrm{w} / \mathrm{w})$ at feed flow of $14 \mathrm{~L} / \mathrm{min}$. With increase in feed flow (>14 L/min), $\mathrm{CH}_{4}$ 


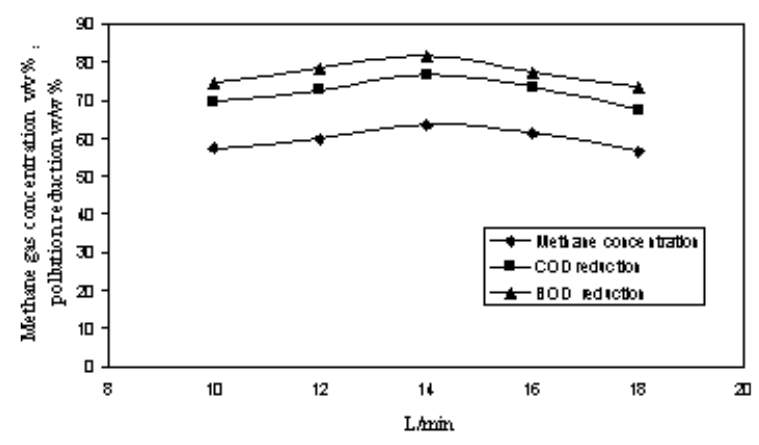

Figure 9: Effect of feed flowrate on COD and BOD reduction

gas yield and concentrations and the removal of COD and BOD from wastewaters were decreased as well. Feed flow of $14 \mathrm{~L} / \mathrm{min}$ was the optimum for maximum yield of $\mathrm{CH}_{4}$ gas with maximum removal of COD and BOD from distillery wastewaters in a fluidized- bed bioreactor. Mechanical forces created by flowing fluids, hydrodynamic, and interfacial tension which can disturb the bacterial population to some extend [32]. In the three-phase fluidized -bed bioreactor, there exists a pressure difference between inlet and outlet of the feed. Increase in flow rates can disturb the elaborate shape of enzyme molecule of the bacteria to such a degree that denaturation of the protein occurred and deactivated the methagenic bacterial growth. Therefore, the yields of $\mathrm{CH}_{4}$ gas and removal of pollution loads decreased with increase in feed flow $(>14 \mathrm{~L} / \mathrm{min})$ as well.

\subsection{Analysis of Monod model with COD loading}

The specific bacterial growth rate in presence of distillery wastewaters as substrate i.e. COD loading at different flow rates at optimum biomethanation conditions in three-phase fluidized-bed bioreactor is shown in Figure 10. The specific bacterial growth rate $(\mu)$ was determined by plotting growth rate against limiting substrate COD loading by using Monod Growth Model [32] as shown:

$$
\mu=\mu_{\max }\left[\frac{S}{K_{S}+S}\right]
$$

where, $K_{s}$ is limiting substrate COD loading at which the specific growth rate $(\mu)$ was half of maximum growth rate $\mu_{\max }$ i.e. $\mu=\mu_{\max } / 2$, at $K_{s}=S$ (upto linear portion of the curve). The model indicated a division between the lower concentration range, where was strongly (linearly) dependent on $S$, and the higher concentration range, where became independent of $S$ (curve portion of Figure 10); where, $S$ is the limiting substrate COD loading.

With increase in COD loading (OLR), the growth of bacteria increased $\left(<39.513 \mathrm{~kg} \mathrm{COD} \mathrm{m}^{-3} \mathrm{~h}^{-1}\right)$, then it decreased $\left(>39.513 \mathrm{~kg} \mathrm{COD} \mathrm{m}^{-3} \mathrm{~h}^{-1}\right)$. The specific growth rate $(\mu)$ was $1.18 \mathrm{~h}^{-1}$ (upto linear portion of Figure 10) and maximum growth rate $\left(\mu_{\max }=2 \mu\right)$ is $2.36^{-1}$ respectively. The kinetic parameter, $K s$ was determined as $30.328 \mathrm{~kg} \mathrm{COD} \mathrm{m}^{-3}$ $\mathrm{h}^{-1}$. The bacterial yield coefficient $(Y=X / S=$ maximum sp. growth of bacteria /COD consumed) was determined as

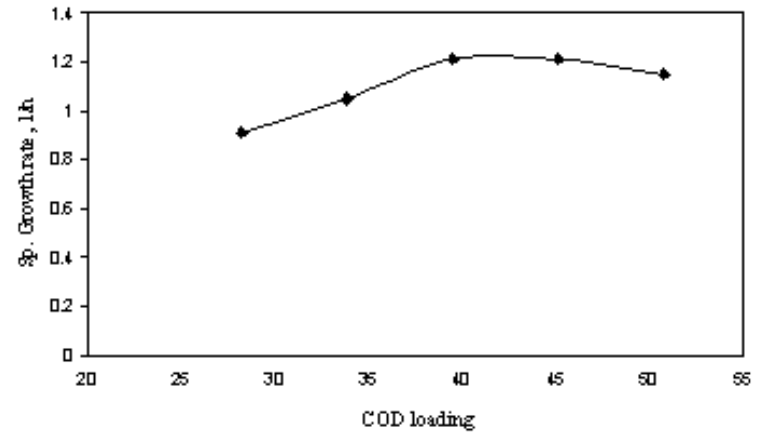

Figure 10: Monod growth model

$0.0395 / \mathrm{kg} \mathrm{COD} \mathrm{m}^{-3} \mathrm{~h}^{-1}$ at optimum biomethanation parameters.

\subsection{Kinetic model of fluidized-bed bioreactor}

The kinetics of anaerobic biomethanation of the distillery wastewaters in three-phase fluidized-bed bioreactor was investigated. The first order rate equation was of the form:

$$
-\ln \left(S / S_{0}\right)=k t
$$

where, $S_{0}$ and $S$ are COD consumptions at time $=0$ and at

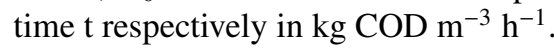

A straight line (Figure 11) was obtained by plotting digestion time $(t)$ against $-\ln \left(S / S_{0}\right)$. From Figure 11, the kinetic rate constant $(k)$ was measured as $0.31 \mathrm{~h}^{-1}$ in fluidized-bed bioreactor. Therefore, it followed the first order rate kinetics. Yield of $\mathrm{CH}_{4}$ gas as against $\mathrm{COD}$ (substrate) consumption at different OLR is shown in Figure 12. With increase in COD consumption, the yield of $\mathrm{CH}_{4}$ gas increases upto $0.530 \mathrm{~m}^{3}$ $/ \mathrm{kg} \mathrm{COD} \mathrm{m}^{-3} \mathrm{~h}^{-1}$ (COD consumption $30.37 \mathrm{~kg} \mathrm{COD} \mathrm{m}^{-3}$ $\mathrm{h}^{-1}$ ), then it declined though COD removal was increasing.

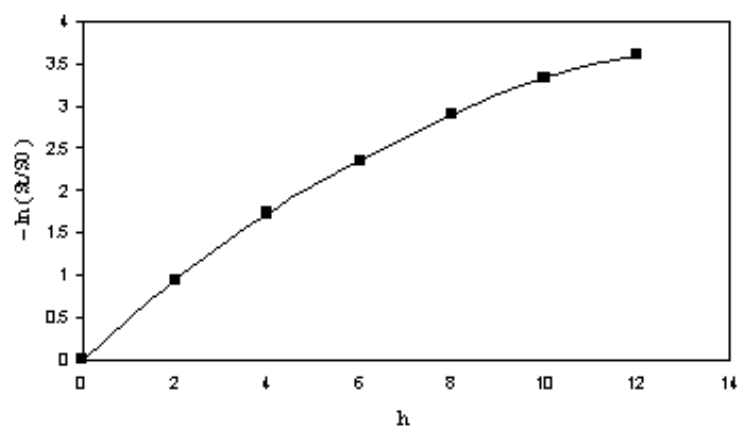

Figure 11: First order rate kinetics

Substrate COD consumption at different flow rates (OLR) vs kinetic parameter (rate constant, $k$ ) plot is shown in Fig.13. $k$ is a measurement of the overall performance of the fluidized-bed bioreactor depends on COD consumption. $k$ has a maximum of $0.0219 \mathrm{~h}^{-1}$ for COD consumption 30.37 $\mathrm{kg} \mathrm{COD} \mathrm{m}{ }^{-3} \mathrm{~h}^{-1}$ (Figure 13). The non-linear equation which fitted the curve of kinetic parameter $(k)$ vs COD consumption is,

$$
k=-0.0196 S^{2}+0.1452 S+0.01321
$$




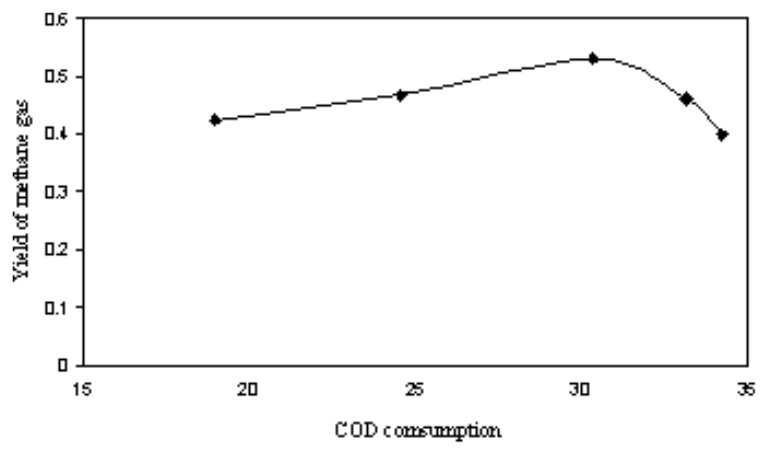

Figure 12: Yield of methane with COD consumption

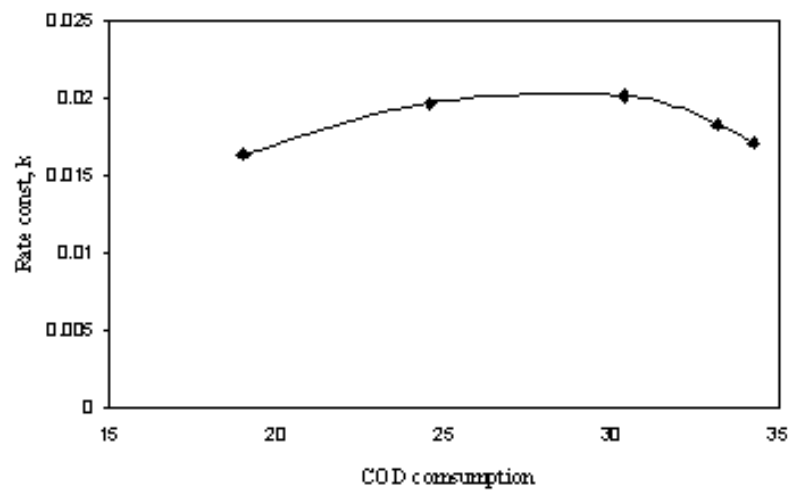

Figure 13: Variation of kinetic parameter with COD consumption

Substrate COD consumption vs maximum specific growth rate $\left(\mu_{\max }\right)$ is shown in Fig. 14. $\mu_{\max }$ showed a non-linear relationship with COD removal. $\mu_{\max }$ is a measurement of the overall performance of the bacterial growth in three-phase fluidized-bed bioreactor and has a value of $2.58 \mathrm{~h}^{-1}$ for COD consumption $30.37 \mathrm{~kg} \mathrm{COD} \mathrm{m}^{-3} \mathrm{~h}^{-1}$ (Figure 14). The nonlinear equation which fitted the curve [15] of $\mu_{\max }$ vs COD consumption is:

$$
\mu_{\max }=-0.0132 S^{2}+0.1145 S+0.1125
$$

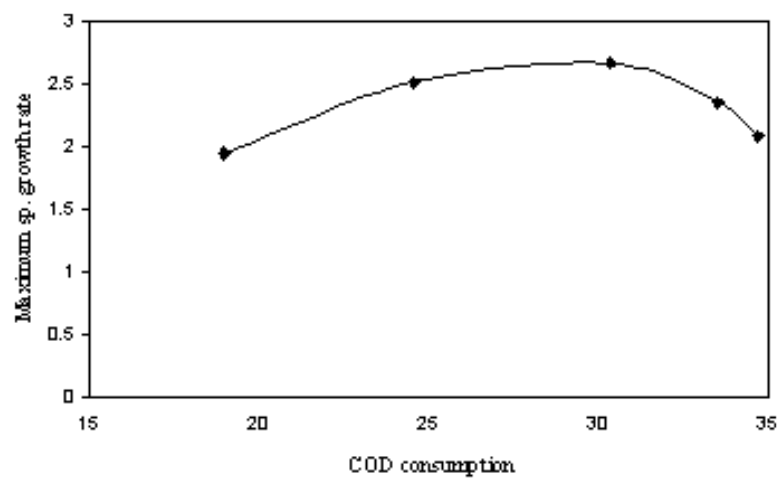

Figure 14: COD consumption vs maximum specific growth rate

\subsection{Hydrodynamics of fluidized-bed bioreactor}

The hydrodynamics of three-phase fluidized-bed bioreactor for $\mathrm{CH}_{4}$ gas yield is shown in Figure 15 and 16. The maximum expansion of the bed was observed as $23.67 \mathrm{~cm}$ at optimum feed flow of $18 \mathrm{~L} / \min \left(0.018 \mathrm{~m}^{3} /\right.$ in $)$ with optimum process parameters. It was observed that the increase of the bed expansion increases bacterial mass in the bioreactor. The hydrodynamic pressure ( $\Delta p$, pressure difference between inlet and out let of feed) were 1393.265, 1562.88, $1708.264,1889.994$ and $1974.802 \mathrm{kN} / \mathrm{m}^{2}$ for corresponding fluid velocity of $0.01,0.012,0.014,0.016$ and $0.018 \mathrm{~m}^{3} / \mathrm{min}$ respectively. The fluid velocity was plotted against $\Delta p$ in the three-phase fluidized-bed bioreactor (Figure 15). It was observed that the increase of the feed flow (fluid velocity) increases $\Delta p$ in the bioreactor. The linear relationship between $\Delta p$ vs feed flow $(u)$ is:

$$
u=72.692(\Delta p)+1352.00
$$

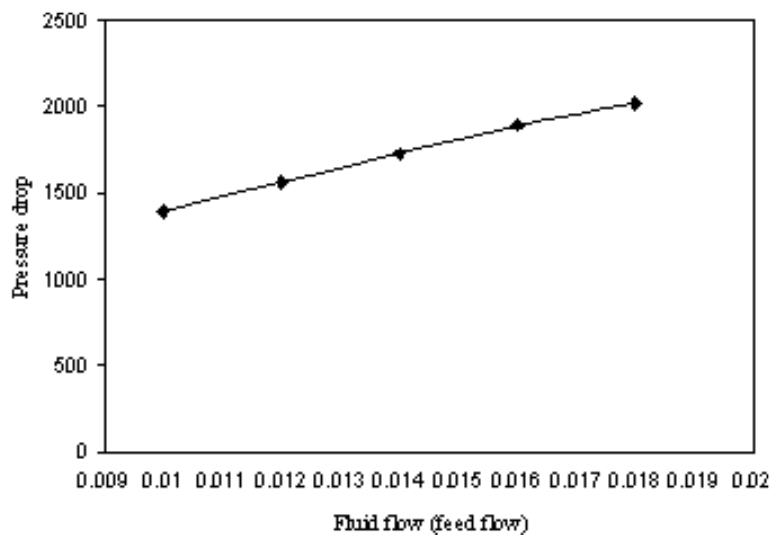

Figure 15: Pressure drop with fluid flow

$\mathrm{CH}_{4}$ gas yield was also plotted against $\Delta p$ (Figure 16). The non-linear equation which fitted the curve is:

$$
Y_{\mathrm{CH}_{4}}=-0.0154(\Delta p)^{2}+0.1378(\Delta p)+0.04122
$$

where, $\mathrm{Y}_{\mathrm{CH}_{4}}$ is the $\mathrm{CH}_{4}$ yield.

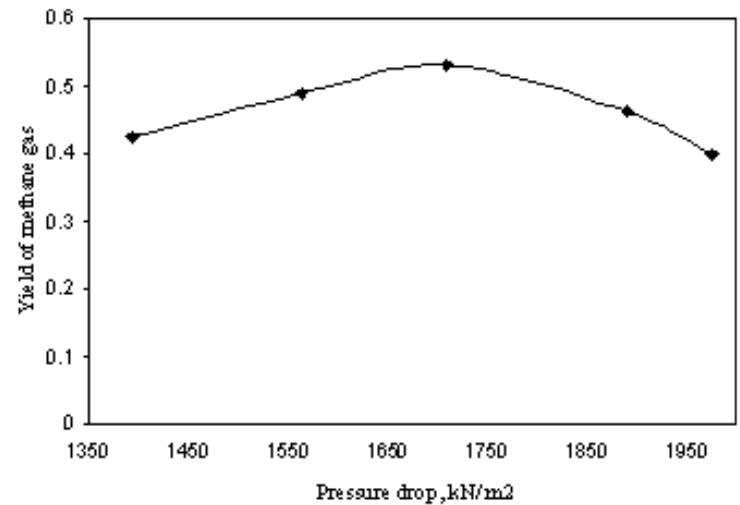

Figure 16: Methane yield with pressure drop 


\section{Conclusion}

Generation of $\mathrm{CH} 4$ gas from distillery wastewaters in anaerobic fluidized- bed bioreactor using activated aerobic sewage sludge was an effective biomethanation process. The optimum digestion time was $8 \mathrm{~h}$ and optimum initial $\mathrm{pH}$ of feed was found to be 7.5 respectively. Optimum temperature of feed was $40^{\circ} \mathrm{C}$. The optimum flow rate of feed in fluidized bed bioreactor was $14 \mathrm{~L} / \mathrm{min}$ with OLR of $39.513 \mathrm{~kg}$ COD $\mathrm{m}^{-3} \mathrm{~h}^{-1}$. The maximum expansion of the bed was observed as $23.67 \mathrm{~cm}$ at optimum feed flow of $14 \mathrm{~L} / \mathrm{min}$. The maximum biogas yield in anaerobic fluidized-bed bioreactor was $0.835 \mathrm{~m}^{3} / \mathrm{kg} \mathrm{COD} \mathrm{m}^{-3} \mathrm{~h}^{-1}$. The maximum concentration of $\mathrm{CH}_{4}$ gas at optimum biomethanation process parameters was found as 63.56 percent (v/v) in the anaerobic fluidized-bed bioreactor with mixed aerobic sludge bacteria. At optimum condition, maximum $\mathrm{CH}_{4}$ gas yield, $\mathrm{COD}$ and BOD removal were $0.530 \mathrm{~m}^{3} / \mathrm{kg} \mathrm{COD} \mathrm{\textrm {m } ^ { - 3 }} \mathrm{h}^{-1}, 76.82$ percent $(\mathrm{w} / \mathrm{w})$ and 81.65 percent $(\mathrm{w} / \mathrm{w})$ from the distillery wastewaters, respectively. A steady state was achieved with $76.82 \%$ COD reduction at OLR of $39.513 \mathrm{~kg} \mathrm{COD} \mathrm{m}^{-3} \mathrm{~h}^{-1}$ (digestion time $8 \mathrm{~h}$ ). The optimization of these parameters enabled a stable functioning of the process and allowed the application of high COD loading. The rate constant $(k)$ was measured as $0.31 \mathrm{~h}^{-1}$ in fluidized-bed bioreactor and followed a first order rate equation. The specific growth rate $(\mu)$ was $0.99 \mathrm{~h}^{-1}$ and maximum sp. growth rate $\left(\mu_{\max }\right)$ was $1.98 \mathrm{~h}^{-1}$ respectively. The bacterial yield coefficient $(Y)$ was determined as $0.319 / \mathrm{kg} \mathrm{COD} \mathrm{m}^{-3} \mathrm{~h}^{-1}$ at optimum parameters. It had been found that variation of kinetic parameter $(k)$ with COD consumption and maximum sp. growth rate $\left(\mu_{\max }\right)$ followed a non-linear relationship with COD loading. The mathematical modeling was also analyzed for hydrodynamic pressure $(\Delta p)$ vs fluid velocity $(u)$ and hydrodynamic pressure $(\Delta p)$ with respect to $\mathrm{CH}_{4}$ gas yields. The linear and non-linear equations which fitted the models were obtained.

\section{References}

[1] McInerney MJ and Bryant MP, in Fuel Gas Production from Biomass, Volume 1, CRC Press, 1981. pp. 19-46

[2] McInerney MJ and Bryant MP, in Anaerobes and anaerobic Infections, Gustaro Fischer Verlag, 1980. p. 117

[3] Lamptey J, Moo-Young M and Sullivan HF, in Bioenergy, Wiley Eastern Ltd., 1990. p. 6

[4] Brown NL and Tata PBS, Bioenergy, Wiley Eastern Ltd., 1990. p. 67

[5] Klass D, Energy from Biomass and Waste VII, Institue of Gas Technology, 1983

[6] Higgin $\mathrm{J}$ and $\mathrm{H} \mathrm{KJ}$, Chemical and Engineering News, 1983. 61(11):p. 28

[7] Henze M and Harremoaes P, Anaerobic treatment of wastewater in fixed film reactors: a literature review, Water science and technology, 1983. 15(8-9):pp. 1-101

[8] Perez M, Rodriguez-Cano R, Romero L and Sales D, Performance of anaerobic thermophilic fluidized bed in the treatment of cutting-oil wastewater, Bioresource Technology, 2007. 98(18):pp. 3456 - 3463. doi:DOI:10.1016/j.biortech.2006.11.005

[9] Acharya BK, Mohana S and Madamwar D, Anaerobic treatment of distillery spent wash - A study on upflow anaerobic fixed film bioreactor, Bioresource Technology, 2008. 99(11):pp. 4621 - 4626, exploring Horizons in Biotechnology: A Global Venture. doi:DOI: 10.1016/j. biortech.2007.06.060
[10] Sakoda A, Sadakata M, Koya T, Furusawa T and Kunii D, Gasification of biomass in a fluidized bed, The Chemical Engineering Journal, 1981. 22(3):pp. 221 -227. doi : DOI : 10.1016/0300-9467 (81) 80017-2

[11] Tesch W, Schneider K and Bachofen R, Performance of an anaerobic filter for purification and methane production from waste water of a sugar refinery, Process Biochemistry, 1983. 14(1):pp. 34-37

[12] Switzenbaum MS, Anaerobic fixed film wastewater treatment, Enzyme and Microbial Technology, 1983. 5(4):pp. $242-250$. doi: DOI : 10.1016/0141-0229(83) 90072-8

[13] Wu CS, Huang JS and Chou HH, Influence of internal biogas production on hydrodynamic behavior of anaerobic fluidized-bed reactors, Water Research, 2006. 40(1):pp. 126 - 136. doi :DOI: 10.1016/j . watres.2005.10.036

[14] Cho YK, Performance of a two-stage methane digestor for alcohol stillage derived from sugarcane molasses, Biotechnology Letters, 1983. 5(8):pp. 555-560. doi : DOI : 10.1007/BF01184948

[15] Banerjee S and Biswas GK, Studies on biomethanation of distillery wastes and its mathematical analysis, Chemical Engineering Journal, 2004. 102(2):pp. 193 - 201. doi: DOI:10.1016/j.cej. 2004.05. 006

[16] Bull MA, Sterritt RM and Lester JN, The distribution of bacterial activity in an anaerobic fluidized bed reactor, Water Research, 1984. 18(8):pp. 1017 - 1020. doi :DOI : 10.1016/0043-1354(84) 90253-7

[17] Borja R, Martn A, Luque M and Durn M, Kinetic study of anaerobic digestion of wine distillery wastewater, Process Biochemistry, 1993. 28(2):pp. 83 - 90. doi : DOI : 10.1016/0032-9592 (93) 80011-5

[18] Borja R, Garrido S, Martnez L, Ramos-Cormenzana A and Martn A, Kinetic study of anaerobic digestion of olive mill wastewater previously fermented with Aspergillus terreus, Process Biochemistry, 1993. 28(6):pp. 397 - 404. doi : DOI : 10.1016/0032-9592 (93) 80027-E

[19] He WS and Ping Z, Organic matter degradation kinetics in a fluidized bed bioreactor, Water Research, 1994. 28(9):pp. 2021 - 2028. doi: DOI : 10.1016/0043-1354(94) 90177-5

[20] Lettinga G, van Velsen AFM, Hobma SW, de Zeeuw W and Klapwijk A, Use of the upflow sludge blanket (USB) reactor concept for biological wastewater treatment, especially for anaerobic treatment, Biotechnology and Bioengineering, 1980. 22(4):pp. 699-734. doi:DOI:10.1002/bit. 260220402

[21] Manjunath DL, Mehrotra L and Mathur RP, IAWPC Technical Annual, 1988. 15:p. 23

[22] Olthof M and Oleszkiewicz J, Chemical Engineering, 1982. 89(23):p. 121

[23] Gohil A and Nakhla G, Treatment of tomato processing wastewater by an upflow anaerobic sludge blanket-anoxic-aerobic system, Bioresource Technology, 2006. 97(16):pp. 2141 - 2152. doi:DOI: 10.1016/j.biortech. 2005.09.017

[24] Buzzini A and Pires E, Evaluation of a upflow anaerobic sludge blanket reactor with partial recirculation of effluent used to treat wastewaters from pulp and paper plants, Bioresource Technology, 2007. 98(9):pp. 1838 - 1848. doi:DOI:10.1016/j.biortech. 2006. 06.030

[25] Vandan BL and Kennedy KJ, Water Science and Technology, 1982. 15(8-9):p. 359

[26] Pol LH and Lettinga G, Water Science and Technology, 1986. 18(2):p. 41

[27] Daniels L, Biological methanogenesis: physiological and practical aspects, Trends in Biotechnology, 1984. 2(4):pp. 91 - 98. doi :DOI : 10.1016/S0167-7799 (84) 80004-9

[28] Hossain SM, Das M and Anantharaman N, Indian Journal of Chemical Technology, 2009. 16(1):p. 58

[29] Sivaguru K, Hossain SM, Anantharaman N and Begum KMMS, Indian Journal of Envirionmental Protection, 2006. 26(9):p. 788

[30] Trivedy RK and Goel PK, Chemical and biological methods for water pollution studies, Environmental Publications, Karad, India, 1986

[31] Braun RD, Introduction to Chemical Analysis, McGraw-Hill, Inc., Auckland, 1982

[32] Shulter ML and Kargi F, Bioprocess Engineering Basic Concept, Prentice-Hall India, New Delhi, India, 2000 